VISION: Journal of Indian Taxation Volume 4, Issue 2, Jul-Dec 2017, pp. 20-38 doi: 10.17492/vision.v4i02.11782

\title{
Budgetary Impacts of Central Fiscal Transfers in India: Evidence from State Level Data
}

\author{
Prasant Kumar Panda*
}

\begin{abstract}
The paper empirically examines the impacts of federal transfers on States' tax efforts and expenditure taking into consideration a panel data set of 22 Indian States for the time-period 1980-81 to 2007-08. Dynamic panel equations are specified and system GMM estimation techniques are adopted to obtain the regression coefficients. The results suggest that federal transfers have adverse incentives on budgetary initiatives of States in mobilizing their own tax resources and regulating expenditure. Federal transfers as a whole adversely affect states' Tax-GSDP ratio and per capita own tax revenues. Similarly, federal transfers have important influence on the size and pattern of States' spending. All categories of States' expenditure like revenue expenditure, capital disbursements and aggregate expenditure are stimulated by the large availability of Central transfers. Expenditure impact of transfers is more realised on revenue expenditure than capital disbursements. The author calls for review of existing design of transfers and criteria, proper assessment of non-plan revenue deficit grants, review of ratio of specific transfers to lump-sum transfers and increasing the scope of formula based transfers to handle adverse budgetary incentives of federal transfers.
\end{abstract}

Keywords: Federal transfers; Federal grants; Incentive effects; Budgetary Impacts; Allocative effects; State fiscal policy; Dynamic panel analysis, GMM estimation.

\subsection{Introduction}

A large literature ${ }^{1}$ on federal fiscal transfers ${ }^{2}$ justifies the rationales of transfers to correct vertical and horizontal fiscal imbalances and internalize spillovers of benefits of public goods between jurisdictions. The system of transfers in a federation should be so designed that it does not detract from the equity and efficiency objectives of federal transfers.

\footnotetext{
*Associate Professor, Department of Economics, Central University of Tamil Nadu, Thiruvarur, Tamil Nadu, India. (Email id: prasantkumar@cutn.ac.in).
} 
Further, as the sub-national finances heavily depend on federal transfers for discharge of constitutional functions and are highly responsive to changes in pattern and design of transfers, the transfers system should have no scope for exerting adverse incentives for fiscal discipline of sub-national units. However, designing transfers to correct fiscal disadvantages of states sometimes provides disincentives to their tax efforts and widely stimulate their spending without an appropriate own tax efforts of them. Unintended economic impacts may be realized due to inappropriate incentives and mechanisms. So, there is a need to examine various effects of federal transfers.

The transfers design in a federal fiscal set up should not influence the budgetary initiatives of the sub-national government in an undesirable manner. Transfers are meant to supplement States' own revenues to discharge their responsibilities and provide an appropriate level of essential services across States. But, transfers should not substitute states' own resource mobilizations and revenues. Besides, design of transfers should not encourage uneconomic spending by the States. In this regard, it is worth making an empirical analysis of the influence of federal transfers on the tax effort and spending of sub-national units. Here, the main research questions are: (i) do federal transfers induce adverse incentives on tax efforts among the States? and (ii) do they stimulate size and pattern of States' spending?

The literature that examines the impacts of federal fiscal transfers mainly focuses on following issues:

(1) Equity and efficiency ${ }^{3}$ impacts of federal transfers: Some literature evaluates the progressivity of federal transfers, and impact of transfers on income equalization, equalizing the standards of public services, offsetting fiscal disparity and efficient provision of public services. The important literature addressing some of these issues include Thimmaiah, 1980; Chelliah et al., 1981; Rao and Aggarwal, 1991; Usher, 1995; Marcelli and Musso, 2001; Blochliser and Charbit, 2008; Werner, 2008; Rangarajan and Srivastava, 2008; and Balasubramanian, Govindadass and Panda, 2012.

(2) Budgetary effects of federal transfers: Some studies examine how federal transfers influence States' budgetary/fiscal policy. Do they have adverse incentives on fiscal efficiency and encourage fiscal irresponsibility on the part of sub-national government? Some studies analyze expenditure and tax effort impact of central transfers together, while others address them separately. So, analysis of budgetary impacts of federal transfers includes studies pertaining to following issues:

(i) Effect of transfers on tax efforts (Chelliah et al., 1981; Livtac, Ahmad and Bird, 1998; Jha et. al, 1999; Naganathan and Sivagnanam, 2000; Dahlby and Warren, 2002; and Besafamille and Sanguinetti, 2005; Panda 2009); 
(ii) Effect of transfers on expenditure (Bahl and Saunders, 1965; Gramlich, 1968; Auld, 1976; Bahl and Pillai, 1976; Thimmaiah, 1980; Benton, 1992; and Panda and Nirmala, 2013); and

(iii)Fly-paper effect of Lump-sum grants (Gramlich and Galper, 1973; Inman, 1979; Islam and Choudhury, 1989; Lalvani, 2002; Karnik and Lalvani, 2005; and Panda, 2015 ).

However, the present study exclusively tries to examine budgetary impacts of federal fiscal transfers in Indian States. The analysis here is limited to expenditure and tax effort impact of transfers. Studies pertaining to these issues in the Indian context are sparse and they do not consider time periods under coalition governments and changing political scenario. In such circumstances, for narrow political benefits, the States may undermine its fiscal discipline and heavily depend on Centre for transfers. Further, earlier studies were mainly based on static models and failed to capture the dynamics of tax revenues and expenditure in their analysis of impacts of transfers. Attempt is made in the present analysis to overcome the shortcomings of existing literature.

The remainder of the work is structured as follows: The data and methodology used in the study are analyzed in section-2. Section- 3 outlines the empirical results and provides discussion. Observations and conclusive remarks are given in the last section.

\subsection{Data and Methodology}

The present study analyzes the effects of aggregated and channel specific Central transfers on tax efforts and expenditure of States in India, a developing economy. The study uses a longer data set for analysis, which includes 22 Indian States for a period of 28 years (1980-81 to 2007-08) under different political and economic regimes. In order to maintain uniformity that data for Chhattisgarh, Jharkhand and Uttaranchal are added with the same of their originating states. Due to lack of continuous data for the whole study period the states like Arunachal Pradesh, Goa and Mizoram are not considered for study. Variables are carefully selected in the study to measure tax efforts and expenditure pattern of States. Own tax revenue-Gross State Domestic Product(GSDP) ratio is used as dependent variable and as a proxy to measure tax efforts of states. Alternatively, percapita own tax revenue is used for the same purpose. In a similar manner, various types of state expenditure like revenue expenditure, capital disbursements and their aggregates in per capita terms are alternatively used as dependent variables in the model to analyse impacts of transfers on spending. The explanatory variables which hypothesized to influence tax efforts and spending are mainly per capita aggregated central transfers which include shared tax and grants. 
Besides various channel specific transfers like statutory transfers recommended by the Finance Commission, plan transfers by The Planning Commission and discretionary transfers (Central plan and centrally sponsored grants) by Central Ministries, in per capita terms are used in order to understand their differential impact. Besides some control variables like Non-primary sectoral contribution, Per capita GSDP, urbanization and density of population are used in all models to control for economic and demographic variations.

State GSDP data have been taken from the Central Statistical Organization (CSO) and previous series data have been spliced to make them comparable with 19992000 series. Per capita GSDP at constant price (1999-2000 prices) is used in the study. Non-primary sectoral contribution (NPRSC) is obtained from CSO by adding up the contributions of the secondary and tertiary sectors and the same is expressed as a per cent of total GSDP. The urbanization proxy is measured by considering the urban population as percent to total population of a State. Data related to state population, urban population and density of population are taken Census of India (Registrar General of India). Mid-year figures for these data are obtained by interpolating decadal data. The fiscal variables used in the study like own tax revenue, expenditure of states are taken from various volumes of State Finances - A Study of Budgets and RBI Bulletins and those data have been deflated by GSDP deflator to get value in constant terms.

The dependent variables used in the models are highly auto-correlated and persistent. Further, current values of tax revenues and expenditures may depend on past values or structural uncertainties. So, dynamic panel data models are specified to capture the dynamics of tax revenues and expenditures, after controlling unobserved State specific factors and linear time trend. Time Trend is used as a control variable to control trend component of variables. Besides data set used here has long time component.Partial correlation matrix is computed to analyse the correlation among the explanatory variables. The variables which are highly correlated are omitted from the model. All the coefficients of explanatory variables analysing the impact of aggregate transfers are within limits. But, in case of channel specific transfers, partial correlation coefficient of PCSTT is slightly higher with PCGSP and PCDSG. As the main objective is verify the impact of channel specific impact of transfers, these variables are not omitted from the study. However, as a robustness checking of the results, separate analyses are made by considering these variables individually along with other control variables.

The following equations have been estimated to examine budgetary impacts of federal transfers: 
(i) Impact on States' tax effort:

OTSDP $_{\mathrm{it}}=\beta_{0}+\beta_{1}$ OTSDP $_{\mathrm{it}-1}+\beta_{2}$ PGSDP $_{\mathrm{it}}+\beta_{3}$ NPRSC $_{\mathrm{it}}+\beta_{4} \mathrm{URBAN}_{\mathrm{it}}+\beta_{5}$ PCSTT $_{\mathrm{it}}+$ $\beta_{6}$ PCGSP $_{\text {it }}+\beta_{7}$ PCDSG $_{\text {it }}+\beta_{8}$ TREND $_{\mathrm{t}}+\mathrm{u}_{\mathrm{i}}+\varepsilon_{\mathrm{it}}$

An alternative measure to analyze the tax effort impact of transfers is considered by changing the dependent variable. The specific equation is:

PCOTR $_{\mathrm{it}}=\beta_{0}+\beta_{1} \mathrm{PCOTR}_{\mathrm{it}-1}+\beta_{2} \mathrm{PGSDP}_{\mathrm{it}}+\beta_{3} \mathrm{NPRSC}_{\mathrm{it}}+\beta_{4} \mathrm{URBAN}_{\mathrm{it}}+\beta_{5} \mathrm{PCSTT}_{\mathrm{it}}+$ $\beta_{6}$ PCGSP $_{i t}+\beta_{7}$ PCDSG $_{i t}+\beta_{8}$ TREND $_{t}+u_{i}+\varepsilon_{i t}$

Further, to analyze the impact of overall transfers on tax effort, keeping control variables same, the dependent variables are alternatively regressed on per capita aggregate revenue transfers from Centre (PARTC). The specific equation for the analysis is:

OTSDP $_{\text {it }}=\beta_{0}+\beta_{1}$ OTSDP $_{\text {it- } 1}+\beta_{2}$ PGSDP $_{\text {it }}+\beta_{3}$ NPRSC $_{\text {it }}+\beta_{4}$ URBAN $_{i t}+\beta_{5}$ PARTC $_{\text {it }}+$ $\beta_{6}$ TREND $_{\mathrm{t}}+\mathrm{u}_{\mathrm{i}}+\varepsilon_{\mathrm{it}}$

Alternatively following equation is used.

PCOTR $_{\text {it }}=\beta_{0}+\beta_{1}$ PCOTR $_{\text {it }-1}+\beta_{2}$ PGSDP $_{i t}+\beta_{3}$ NPRSC $_{i t}+\beta_{4}$ URBAN $_{i t}+\beta_{5}$ PARTC $_{i t}+$ $\beta_{6}$ TREND $_{\mathrm{t}}+\mathrm{u}_{\mathrm{i}}+\varepsilon_{\mathrm{it}}$

(ii) Impact on States' spending:

PCEXP $_{\text {hit }}=\beta_{0}+\beta_{1}$ PCEXP $_{\text {hit }-1}+\beta_{2}$ PGSDP $_{\text {it }}+\beta_{3}$ POPDN $_{\text {it }}+\beta 4$ PCSTT $_{\text {it }}+\beta_{5}$ PCGSP $_{\text {it }}+\beta_{6}$ PCDSG $_{i t}+\beta_{7}$ TREND $_{t}+u_{i}+\varepsilon_{i t}$

Further, these dependent variables are also alternatively regressed on per capita aggregate revenue transfers from Centre (PARTC) and the control variables selected to analyse the impact of transfers as a whole. The model used for the same is:

PCEXP $_{\text {hit }}=\beta_{0}+\beta_{1}$ PCEXP $_{\text {hit- } 1}+\beta_{2}$ PGSDP $_{\text {it }}+\beta_{3}$ POPDN $_{\text {it }}+\beta_{4}$ PARTC $_{\text {it }}+\beta_{5}$ TREND $_{\mathrm{t}}$ $+\mathrm{u}_{\mathrm{i}}+\varepsilon_{\mathrm{it}}$

Where,

OTSDP $=$ own tax revenue-GSDP ratio;

$\mathrm{PCOTR}=$ per capita own tax revenue;

$\operatorname{PCEXP}_{\mathrm{h}}=$ per capita State expenditure of type $\mathrm{h}$; and $\mathrm{h}=1, \ldots \ldots \ldots, 3$;

$\mathrm{PCEXP}_{1}=$ per capita aggregate expenditure of the States (PCAEX);

PCEXP $_{2}=$ per capita revenue expenditure of the State (PCREX);

PCEXP $_{3}=$ per capita capital disbursement $(\mathrm{PCCAD})$;

PGSDP = per capita GSDP;

NPRSC $=$ non-primary sectoral contribution;

URBAN = urbanisation;

POPDN = density of population;

PCSTT $=$ per capita statutory transfers from Centre;

PCGSP = per capita grants for State plan;

PCDSG = per capita discretionary grants; 
PARTC $=$ per capita aggregate revenue transfer from Centre;

$\mathrm{i}=1 \ldots \ldots \ldots . .22 ; \mathrm{t}=$ time $(1,2,3, \ldots, 28) ; \mathrm{t}=$ current year; $\mathrm{i}=$ State;

$\varepsilon=$ random error terms; $u=$ panel specific effect to control for state specific variations in terms of dummies; $\beta_{0}=$ intercept coefficient; $\mathrm{TREND}_{\mathrm{t}}=$ linear time trend; and $\beta_{1 \ldots \ldots . . .} \beta_{8}=$ coefficients of explanatory variables.

Table 1 shows the hypothesised relations for variables selected in the above equations.

Table 1: Hypothesized Relations of Selected Variables

\begin{tabular}{|c|c|c|c|c|c|c|c|c|c|}
\hline \multicolumn{10}{|c|}{ Table 1: Expected Signs } \\
\hline \multirow[t]{2}{*}{$\begin{array}{c}\text { Dependent } \\
\text { Variable }\end{array}$} & 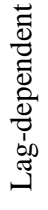 & 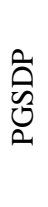 & $\begin{array}{l}U \\
\mathscr{n} \\
\tilde{z} \\
z\end{array}$ & $\begin{array}{l}\text { Z } \\
\text { 离 } \\
\text { 占 }\end{array}$ & 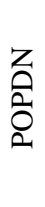 & $\underbrace{E}_{2}$ & $\begin{array}{l}\vec{n} \\
0 \\
0\end{array}$ & 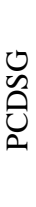 & 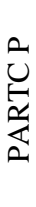 \\
\hline & \multicolumn{9}{|c|}{ Equations examining channel specific impact of transfers } \\
\hline OTSDP / PCOTR & + & + & + & + & $*$ & - & - & - & * \\
\hline $\begin{array}{l}\text { PCAEX/ PCREX/ } \\
\text { PCCAD }\end{array}$ & + & + & $*$ & $*$ & + & + & + & + & $*$ \\
\hline & \multicolumn{9}{|c|}{ Equations examining impact of transfers in aggregate terms } \\
\hline OTSDP / PCOTR & + & + & + & + & $*$ & $*$ & $*$ & $*$ & - \\
\hline $\begin{array}{l}\text { PCAEX/ PCREX/ } \\
\text { PCCAD }\end{array}$ & + & + & $*$ & $*$ & + & $*$ & $*$ & $*$ & + \\
\hline
\end{tabular}

In the above models, considering the use of lagged dependent variable as regressor, both Ordinary Least Square estimator and within estimator is inconsistent. In that case, GMM estimation technique is widely used. More specifically, System GMM estimator has been employed in the present study, to estimate the coefficients. Robust standard errors for correcting heteroscedasticity and two step estimators are used wherever necessary. Post estimation tests like Arellano Bond test is used to assess the presence of auto-correlation at the first differenced error and Sargan test is employed to verify the validity of over identifying restriction in the model.

\subsection{Empirical Results and Discussions}

\subsection{Results pertaining to impact of transfers on states' tax effort}

Own tax revenue GSDP ratio(OTSDP) and per capita own tax revenue(PCOTR) are alternatively regressed on channel specific and aggregate transfers along with 
specified control variables to verify the impact of transfers on tax efforts. The set of explanatory variables remain same for both the dependent variables. While Table 2 reports the linear specification results of the channel (category) specific effect of transfers on various measures of tax effort, Table 3 presents those of transfers as a whole.

Table 2: Impact of Channel Specific Transfers on States' Tax Effort: Estimation Results of Linear specification (GMM)

\begin{tabular}{|c|c|c|}
\hline Dependent Variable & $\begin{array}{c}\text { (1) } \\
\text { OTSDP }\end{array}$ & $\begin{array}{c}(2) \\
\text { PCOTR@ }\end{array}$ \\
\hline Lag Dependent & $\begin{array}{l}0.7999 * \\
(22.72)\end{array}$ & $\begin{array}{c}0.1147 * * * \\
(1.93)\end{array}$ \\
\hline PGSDP & $\begin{array}{c}-0.00002 \\
(-1.48)\end{array}$ & $\begin{array}{c}0.0445^{*} \\
(17.50)\end{array}$ \\
\hline NPRSC & $\begin{array}{c}0.02538 * \\
(5.05)\end{array}$ & $\begin{array}{c}5.7628 * \\
(4.55)\end{array}$ \\
\hline URBAN & $\begin{array}{c}0.0289 * * \\
(2.13)\end{array}$ & $\begin{array}{c}17.292 * * * \\
(1.85)\end{array}$ \\
\hline PCSTT & $\begin{array}{c}-0.0002753 * * \\
(-2.12)\end{array}$ & $\begin{array}{c}-.0925772 * \\
(-5.97)\end{array}$ \\
\hline PCGSP & $\begin{array}{c}0.00019 * \\
(3.49)\end{array}$ & $\begin{array}{l}0.0079 \\
(0.69)\end{array}$ \\
\hline PCDSG & $\begin{array}{c}0.00026 \\
(0.35)\end{array}$ & $\begin{array}{c}.3343 * * * \\
(1.81)\end{array}$ \\
\hline $\begin{array}{l}\text { Wald Test } \\
\text { P-value }\end{array}$ & $\begin{array}{c}1848.83 * \\
0.0000\end{array}$ & $\begin{array}{c}5016.25^{*} \\
0.0000\end{array}$ \\
\hline $\begin{array}{l}\text { Sargan Test } \\
\text { P-Value }\end{array}$ & - & - \\
\hline $\begin{array}{l}\text { AB Test } \mathrm{m} 1 \\
\text { P-value }\end{array}$ & $\begin{array}{c}-1.0099 \\
0.3125\end{array}$ & $\begin{array}{c}-1.4485 \\
0.1475\end{array}$ \\
\hline $\begin{array}{l}\text { AB Test } \mathrm{m} 2 \\
\mathrm{P} \text {-value }\end{array}$ & $\begin{array}{l}1.3173 \\
0.1877\end{array}$ & $\begin{array}{c}-0.82402 \\
0.4099\end{array}$ \\
\hline
\end{tabular}

Notes: $t$-values are given in parentheses; *, ** and ***denote significance at $1 \%, 5 \%$ and $10 \%$ level respectively; and @ indicates two step System GMM estimates with heteroskedastic corrected (robust) standard errors.

Columns 1 and 2 in Table 2 show the regression results of analysing the impact of channel specific transfers on States' own tax revenue-GSDP ratio(OTSDP) and Own 
per capita tax revenue (PCOTR) respectively. One important variable of interest PCSTT emerged significant in influencing both OTSDP and PCOTR. The negative sign of PCSTT in both cases, indicates that the transfers recommended by the Finance Commission have negative effect on tax effort of States. This indicates that weights assigned to tax effort criteria in various FC's recommendations have not been reflected and fail to induce a positive pattern between transfers and own-tax revenue. Another possible explanation for this relationship may be the gap-filling approach of the FC. FC is the main channel which recommends around 65 percent of the total transfers to States. Though, it adopts some criteria in distributing transfers among States, suitable measures are not yet developed to assess the revenue short-fall of the States to meet their requirements. But, on the basis of normative assessment, the FC makes provision of nonplan revenue deficit grants to States, where the scope of adverse incentives may arise. The other channel specific transfer variable like PCGSP is found to be significant. It is positively associated with own-tax revenue- GSDP ratio, while it is found to be insignificant for PCOTR. Similarly, PCDSG emerged insignificant for OTSDP and significant and positive for PCOTR. There is no plausible explanation why PCDSG yields significant and positive coefficient for PCOTR. These grants are scheme specific and do not follow any strict criteria in its distribution.

The control variables used in the model like PGSDP, non-primary sectoral contribution (NPRSC) and urbanization emerged statistically significant and positive in influencing own tax revenue per capita (PCOTR). Similarly, NPRSC and URBAN are found to be significant and the sign of the coefficients is obtained in desired line for the equation own tax revenue-GSDP ratio (OTSDP). But, PGSDP is statistically insignificant in influencing OTSDP.

Table-3 displays the results analysing the influence of aggregate transfers on States' tax revenue mobilizations. The variable of interest, PARTC is found to be significant and negatively associated with both own tax revenue-GSDP ratio (OTSDP) and per capita own tax revenue (PCOTR).A one unit increase in PARTC brings a decline of 0.0107 units of PCOTR and 0.0002 percent of OTSDP. This indicates that the Central transfers have adverse incentives on States' own tax mobilizations. The economic and demographic variables used in the study mainly as controls like PGSDP, NPRSC and URBAN emerged significant for OTSDP. All these control variables also emerged to be significant and found to yield positive coefficients for PCOTR. This indicates that increase in urbanization, and structural changes in terms of more industry and service sector contribution increases states' tax revenue mobilizations. 
Table 3: Impact of Aggregate Transfers on States' Tax Efforts: Estimation Results of Linear Specification (GMM)

\begin{tabular}{|l|c|c|}
\hline \multicolumn{1}{|c|}{ Dependent Variable } & $\mathbf{( 1 )}$ & $\mathbf{( 2 )}$ \\
& OTSDP & PCOTR@ \\
\hline Lag dependent & $0.7390^{*}$ & $0.1878^{*}$ \\
& $(19.8)$ & $(3.1)$ \\
\hline PGSDP & $-0.00007^{*}$ & $0.04467^{*}$ \\
& $(-2.75)$ & $(24.56)$ \\
\hline NPRSC & $0.010006^{* * *}$ & $4.40437^{*}$ \\
& $(1.82)$ & $(2.96)$ \\
\hline URBAN & $0.146332^{* *}$ & $15.2226^{*}$ \\
& $(2.55)$ & $(8.25)$ \\
\hline PARTC & $-0.00022^{*}$ & $-0.0107^{* * *}$ \\
& $(-2.63)$ & $(-1.79)$ \\
\hline Wald Test & $4379.72^{*}$ & $2306.40^{*}$ \\
P-value & 0.0000 & 0.0000 \\
\hline Sargan Test & - & - \\
P-Value & - & - \\
\hline AB Test m1 & -1.5598 & -2.0748 \\
P-value & 0.1188 & 0.0380 \\
\hline AB Test m2 & 1.2248 & 0.47315 \\
P-value & 0.2207 & 0.6361 \\
\hline
\end{tabular}

Notes: $t$-values are given in parentheses; $*, * *$ and ${ }^{* * *}$ denote significance at $1 \%, 5 \%$ and $10 \%$ level respectively; and @ indicates two step system GMM estimates with robust standard error.

To verify robustness of the original results, the log-linear specification is used to analyze the impact of aggregate transfers ${ }^{4}$ on tax efforts of States. Log-linear specification also gives similar results for OTSDP and PCOTR, like linear specifications. The sign of the variable of interest remained same. These results are shown in appendix table-A.1. Adverse incentives of Central transfers on state taxes are well inferred from these results. Similarly as it is observed that the partial correlation coefficients of PCSTT with PCGSP and PCDSG are higher, an attempt is made to use them alternatively. The results are presented in table A.2. In the new regressions, the coefficient of PCSTT for own tax-revenue ratio remained significant and negative, but PCGSP and PCDSG emerged insignificant. Though the magnitude of the coefficient varied marginally, the expected sign did not change.

It is credible to argue that the increased state expenditure also forces the states to mobilize more tax resources of their own. So there is a need to include states' 
expenditure as a regresser in determining states' tax efforts and verify the results. However, the states' expenditure and tax revenues are mutually dependent. Keeping this in mindhere tax effort variables like OTSDP and PCOTR are modelled with instrumented expenditure (PCAEX).Instrumental variable estimation techniques are adopted to obtain the coefficients and results are shown in table A.3. Here the results are similar to those of the base line results. The coefficient of PARTC is found to be statistically significant and negative for PCOTR. But it does not significantly influence the tax-GSDP ratio.

\subsection{Results pertaining to impact of transfers on states' spending}

In this sub-section the results pertaining to the effect of Central transfers on States' spending are analyzed. Regression estimation for aggregate expenditure of States (PCAEX) and its components like revenue and capital disbursements in per capita terms are performed. Explanatory variables include channel specific and aggregate Central transfers per capita alternatively along with some control variables. Per capita GSDP (PGSDP) and density of population (POPDN) are used mainly as control variables in all regressions. Table- 4 and table- 5 report findings of the regression analysis.

The regression results of linear specification are presented in Table 4. Results suggest that the variables of interest per capita statutory transfers recommended by FC and per capita grants for State plan which is recommended by PC are significant and positive in influencing total expenditure and its components. The regression coefficients of these variables for PCAEX and PCREX are observed to be more than a unit. Further, the other variable of interest per capita discretionary grants (PCDSG) emerged significant and positive for PCAEX and PCCAD. The only control variable that emerged significant for all categories of expenditure is PGSDP. However, the need-based factor population density (POPDN) is insignificant in influencing States' expenditure. So from the results it is observed that increase in State expenditure is associated with advancement of State in terms State domestic product and more availability of Central transfers.

Table 5 displays the regression coefficients that examine the impact of aggregate Central transfers on States' spending. Per capita aggregate revenue transfers from Centre (PARTC) emerged as significant and positive for all categories of states' spending. The sign of the coefficient of is positive which indicates that Central transfers as a whole positively influence or stimulate States' spending. For one unit increase in PARTC, PCAEX, PCREX and PCCAD increase by 1.412, 1.463 and 0.190 respectively. Central transfers have more influence on revenue expenditure and total expenditure than capital disbursements. 
Table 4: Regression Coefficients of States' Spending: Estimation Results of Linear Specification (GMM)

\begin{tabular}{|l|c|c|c|}
\hline \multirow{2}{*}{ Dependent Variable- } & $(\mathbf{1})$ & $\mathbf{( 2 )}$ & $\mathbf{( 3 )}$ \\
& PCAEX & PCREX & PCCAD @ \\
\hline Lag Dependent & $0.282098^{*}$ & $0.2906618^{*}$ & $0.112195^{*}$ \\
& $(26.63)$ & $(89.03)$ & $(6.68)$ \\
\hline PGSDP & $0.107171)^{*}$ & $0.0982728^{*}$ & $0.026911^{*}$ \\
& $(10.06)$ & $(17.44)$ & $(9.76)$ \\
\hline POPDN & 0.4772863 & 0.1201107 & 0.3430215 \\
& $(0.76)$ & $(0.29)$ & $(0.74)$ \\
\hline PCSTT & $1.312858^{*}$ & $1.801161^{*}$ & $0.197161^{*}$ \\
& $(25.75)$ & $(70.14)$ & $(29.51)$ \\
\hline PCGSP & $1.761675^{*}$ & $1.068913^{*}$ & $0.135335^{*}$ \\
& $(38.07)$ & $(58.85)$ & $(10.02)$ \\
\hline PCDSG & $0.2533465^{* *}$ & 0.0347986 & $0.722019^{*}$ \\
& $(2.28)$ & $(0.59)$ & $(15.64)$ \\
\hline Wald Test & $3456.22^{*}$ & $4533.12^{*}$ & $3420.09^{*}$ \\
P-value & 0.0000 & 0.0000 & 0.0000 \\
\hline Sargan Test & - & - & 16.88456 \\
P-Value & - & - & 1.000 \\
\hline AB Test m1 & -1.31 & -1.5509 & -2.0401 \\
P-Value & 0.187 & 0.1209 & 0.0413 \\
\hline AB Test m2 & -1.44 & -1.6016 & -0.3029 \\
P-Value & 0.1499 & 0.1092 & 0.7620 \\
\hline
\end{tabular}

Notes: $t$-values are in parentheses; *,** and ***denote significance at $1 \%, 5 \%$ and $10 \%$ level respectively; and @ indicates two step system GMM estimates.

Regression analysis is performed on log- linear specification of various expenditures. Here, the variable of interest is the overall transfer that is PARTC. Similar results are obtained in log-linear specification. Results are displayed in appendix table A.4. PARTC significantly and positively affects all categories of expenditure like PCAEX, PCREX and PCCAD. As the partial correlation coefficients of PCSTT with PCGSP and PCDSG are slightly higher, separate regressions for PCAEX considering the channel specific transfer variables separately undertaken to verify the results. The results are shown in table A.5. In the new regressions, the coefficient of PCSTT, PCGSP and PCDSG for per capita aggregate state expenditure remained significant and positive. Though, the magnitude of the coefficient varied marginally, the expected sign did not change and results vindicate the original results. From the overall analysis it is observed 
that the hypothesized relations made regarding association of Central transfers with States' expenditure are justified.

Table 5: Impact of Aggregate Transfers on States' Spending: Estimation Results of Linear Specification (GMM)

\begin{tabular}{|l|c|c|c|}
\hline Dependent Variable- & $\begin{array}{c}(\mathbf{1}) \\
\text { PCAEX }\end{array}$ & $\begin{array}{c}(\mathbf{2}) \\
\text { PCREX }\end{array}$ & $\begin{array}{c}(3) \\
\text { PCCAD@ }\end{array}$ \\
\hline Lag Dependent & $0.2788832^{*}$ & $0.3149355^{*}$ & $0.1342946^{*}$ \\
& $(214.02)$ & $(293.85)$ & $(9.40)$ \\
\hline PGSDP & $0.1119867^{*}$ & $0.0287106^{*}$ & $0.0171413^{*}$ \\
& $(17.68)$ & $(4.64)$ & $(6.63)$ \\
\hline POPDN & $0.5260467^{*}$ & $2.340448^{*}$ & 0.2176918 \\
& $(11.18)$ & $(5.65)$ & $(0.56)$ \\
\hline PARTC & $1.41201^{*}$ & $1.46332^{*}$ & $0.1902652^{*}$ \\
& $(70.06)$ & $(77.34)$ & $(20.66)$ \\
\hline Wald Test & $3487.25^{*}$ & $4599.0^{*}$ & $2349.45^{*}$ \\
P-value & 0.0000 & 0.0000 & 0.0000 \\
\hline Sargan Test & - & - & 18.47626 \\
P-Value & - & - & 1.0000 \\
\hline AB Test m1 & -1.6357 & -1.3554 & -1.975 \\
P-value & 0.1019 & 0.1753 & 0.0483 \\
\hline AB Test m2 & -1.2152 & -1.1354 & -0.63093 \\
P-value & 0.2243 & 0.2562 & 0.5281 \\
\hline
\end{tabular}

Notes: $t$-values are given in parentheses; *,** and ***denote significance at $1 \%, 5 \%$ and $10 \%$ level respectively; and @ indicates two step system GMM estimates.

\subsection{Conclusion}

The main objective of study is to examine the budgetary impacts of federal transfers on States' tax efforts and spending. The results suggest that widespread availability of Central transfers provide adverse incentives on budgetary initiatives of States in mobilizing own tax resources and regulating expenditure. The Central transfers as a whole have a dampening effect on States' tax efforts and it is substituted for States' own tax revenues. Among the channel specific transfers, per capita statutory transfers recommended by the FC emerged negative and significant in influencing the tax effort measures. So, the weights assigned by FCs for tax effort in recommending transfers is 
not reflected in the system to provide a positive association of own-tax revenue with transfers.

The findings from the analysis of expenditure impact of Central transfers suggest that all categories of States' expenditure like revenue expenditure, capital disbursements and states' spending in aggregate are stimulated by the large availability of federal transfers. At disaggregate level, channel specific transfer variables like per capita statutory transfer and per capita grants for State plan are found to be significant and positive for all categories of States' expenditure. Per capita discretionary grant significantly and positively influences per capita aggregate expenditure and per capita capital disbursements. Per capita aggregate transfer emerged significant and found to stimulate all categories of spending. More often the regression coefficient of aggregate transfer variable is found to be more than a unit. It is also observed that the response of revenue expenditure to Central transfers is more than that of capital disbursements. Hence, the study suggests that the Central transfers have important influence on the size and pattern of States' spending.

In order to check the adverse budgetary incentives of Central transfers as well as to address the issues of equity, efficiency and fiscal stability in an effective manner in a developing country like India, the study calls for suitable review of existing design and criteria for transfers to states. In this regard following issues are important:

(i) There is a need for proper co-ordination among resource mediating agencies when designing criteria and incentives. Further, when assigning weight to different criteria used for horizontal distribution of resources, striking a balance between income distance criteria and fiscal performance criteria is desirable.

(ii) Non-plan revenue gaps projected by States for the provision of grants and demand for specific grants should be assessed objectively. Some quantitative methods need to be developed for this in order to check the laxity in States' spending and tax effort.

(iii) In a developing country, the importance of increasing capital expenditure is wellknown. It is clear from the results that the response of capital disbursement to Central transfers is less compared to that of revenue expenditure. Hence, more conditional central transfers can help increase capital expenditure of states.

Acknowldgements: The paper is the modified version of the one presented at the Fourth Annual Conference on Papers in Public Economics organized by the National Institute of Public Finance and Policy, New Delhi during November 7-8, 2012. The author is grateful to Jorge MartinezVazquez, M. Govinda Rao, Tapas Kumar Sen, and Kavita Rao for providing useful suggestions and discussions during the conference. The author's thanks are due to Pratap Ranjan Jena and T. 
Jayaraman for having gone through an earlier draft of the paper and providing useful suggestions. The author's thanks are also due to B. Kamaiah, V. Nirmala and Jaya Krishnakumar for providing useful methodological inputs.The author is solely responsible for errors if there are any.The author also extends his thanks to the University Grants Commission for financial assistance to complete this work.

\section{Endnotes}

1. The important literature that addresses equity rationales of transfers are Buchanan (1950); Oates (1972) and Bradbury et al. (1984). Breton (1965), Oates (1972) and Gramlich (1977) argue for the necessity of transfers for efficient provision of public goods in the presence of spillovers. Transfers are also essential to achievenational policy objectives like a nondistortionary tax system (Oates 1999), or provision of certain merit goods (Musgrave 1961).

2. The expressions like 'Federal transfers and 'Central transfers' are used interchangeably.

3. Efficiency means efficient provision of public services.

4. The log-linear transformation to analyse the impact of channel specific transfers is not considered because some figures for PCGSP and PCDSG take zero values. However it is done for PARTC .

\section{References}

Auld, D.A.L (1976). Provincial grants and local government expenditures. Public Finance Quarterly, 4(3), 295-306.

Bahl, R.W. \& Pillai, V. (1976). Allocative effects of intergovernmental flows in less developed countries: A case study of India. Public Finances/Finances Publiques, 31(1), 73-89.

Bahl, R.W. \& Saunders, R. J. (1965). Determinants of changes in state and local government expenditure. National Tax Journal, 18(1), 50-57.

Balasubramanian, G., Govindadass, J. \& Prasant, K. P. (2012). Finance commission transfers and fiscal equalization in India: Evidence from panel data, International Journal of Finance and Policy Analysis, 4(1), 3-8.

Benton, J. E. (1992). The effects of changes in federal aid on state and local government spending. Publius, 22(1), 71-82. 
Bradbury, K.L., H.F. Ladd, M. Perrault, A. Reschovsky \& J. Yinger (1984). State Aid to offset fiscal disparities among communities. National Tax Journal, 37(2), 151-70.

Besafamille, M. \& Sanguinetti, P. (2005). Exerting local tax effort or lobbying for central transfers? Theory and evidence from Argentina. Retrieved from http://www.nd.edu/ kellogg/publications/ working papers/wps/315pdf.

Blochliser, H. \& Charbit, C. (2008). Fiscal equalization. OECD Economic Studies, 44, 2008/1. Paris: OECD.

Breton, A. (1965). A theory of government grants. Canadian Journal of Economics and Political Science, 31(2), 175-85.

Buchanan, J. (1950). Federalism and fiscal equity. American Economic Review, 40(4), 583-599.

Chelliah, R. J, Aggarwal, O.K., Ghosal, R., Gupta, A. \& Rao, M.G. (1981). Trends and issues in Indian federal finance. New Delhi: Allied Publishers Private Limited.

Dahlby, B. \& Warren, N. (2002). The fiscal incentive effects of the Australian equalisation system. ATAX Discussion Paper Series, 10, University of New South Wales.

Gramlich, E.M. (1968). Alternative federal policies for stimulating state and local expenditures: A comparison of their effects. National Tax Journal, 21(2), 119-29.

Gramlich, E.M. (1977). Intergovernmental grants: A review of the empirical literature. In W. E. Oates (Ed.), The Political Economy of Fiscal Federalism, pp. 219-240. Lexington: Lexington Books, D.C. Heath and Company.

Gramlich, Edward M. \& Harvey Galper (1973). State and local fiscal behavior and federal grant policy. Brookings Papers on Economic Activity, 4(1), 15-65.

Inman, R.P (1979). The fiscal performance of local governments: an interpretative review. In P. Mieszkowski and M. Staszheim (Eds), Current Issues in Urban Economics, pp. 270-321. Baltimore: John Hopkins University Press. 
Islam, M. N. \& Choudhury, S. A. (1989). The flypaper effect and the revenue impact of grants-in-aid. Economics Letters, 30(4), 351-356.

Jha, R., Mohanty, M., Chatterjee, S. \& Chitkara, P. (1999). Tax efficiency in selected Indian states. Empirical Economics, 24(4), 641-654.

Karnik, A. \& Lalvani, M. (2005). Urban local governments and the flypaper effect: evidence from Maharashtra, India. Publius, 35(2), 273-295.

Lalvani, M. (2002). Flypaper effect: Evidence from India. Public Budgeting \& Finance, 22(3), 67-88.

Livtac, J., Ahmad, J. \& Bird, R. (1998). Rethinking decentralization in developing countries. Sector studies series. Washington D.C: The World Bank.

Marcelli, P.J. \& Musso, J.A. (2001). The distributive impact of federal fiscal policy: Federal spending and southern California cities. Urban Affairs Review, 37(2), 163-183.

Musgrave, R. A. (1961). Approaches to a fiscal theory of political federalism.in national bureau of economic research. Public Finances: Needs, Sources and Utilization, (97133). Princeton: Princeton University Press.

Naganathan, M. \& Sivagnanam, K. J. (2000). Federal transfers and tax efforts of states in India. Indian Economic Journal, 47(4), 101-110.

Oates, W. (1972). Fiscal federalism. New York: Harcourt-Brace-Jovanovich.

Oates, W. (1999). An essay on fiscal federalism. Journal of Economic Literature, 37(3), 1120-1149.

Panda, P. K. (2009). Central fiscal transfers and states' own revenue efforts in India: panel data models. Margin: The Journal of Applied Economic Research, 3(3), 223-242.

Panda, P. K. (2015), Fly- paper effect of Fiscal transfers in India: A dynamic panel analysis. The Empirical Econometrics and Quantitative Economics Letters, 4(2), 69-79.

Panda, P. K. \& Nirmala, V. (2013). Central fiscal transfers and states' spending in India: An analysis of incentive effect. Economics Bulletin, 33(2), 1229-1246. 
Rangarajan, C. \& Srivastava, D.K. (2008). Reforming India's Fiscal transfer system: Resolving vertical and horizontal imbalances. Economic and Political Weekly, 43(23), 47-60.

Rao, M.G. \& Aggarwal, V. (1991). Central transfers to offset Fiscal disadvantages of the states: measurement of cost disabilities and expenditure needs. Indian Economic Review, 26(1), 13-33.

Thimmaiah, G. (1980). Allocative efficiency and equity in Indian federal Fiscal transfers. Margin, 12(2), 30-46.

Usher, D. (1995). The uneasy case for equalization payment. Vancouver: Fraser institute.

Werner, J. (2008). Fiscal equalization among the states in Germany. Langen: Institute of Local Public Finance Working paper, 02-2008.

\section{$\underline{\text { Appendix }}$}

Table A.1: Impact of Aggregate Transfers on States' Own Tax Effort Estimation Results of Log- Linear Specification (GMM)

\begin{tabular}{|c|c|c|}
\hline Dependent Variable & OTSDP & LnPCOTR@ \\
\hline Lag Dependent & $\begin{array}{c}0.7910672 * \\
(28.68)\end{array}$ & $\begin{array}{c}0.4511862 * \\
(3.24)\end{array}$ \\
\hline LnPGSDP & $\begin{array}{c}-0.3035444^{*} \\
(-2.29) \\
\end{array}$ & $\begin{array}{c}0.8208616^{*} \\
(3.42)\end{array}$ \\
\hline NPRSC & $\begin{array}{c}0.0279512 * \\
(5.27)\end{array}$ & $\begin{array}{c}0.003048 * * * \\
(1.66)\end{array}$ \\
\hline URBAN & $\begin{array}{c}0.29675^{*} \\
(2.61)\end{array}$ & $\begin{array}{c}-0.0073756 \\
(-0.81)\end{array}$ \\
\hline LnPARTC & $\begin{array}{c}-0.05288^{* * *} \\
(-1.78) \\
\end{array}$ & $\begin{array}{c}-0.19571^{*} \\
(-3.30) \\
\end{array}$ \\
\hline $\begin{array}{l}\text { Wald Test } \\
\text { P-value }\end{array}$ & $\begin{array}{c}1218.29^{*} \\
0.0000\end{array}$ & $\begin{array}{c}406.12 * \\
0.0000 \\
\end{array}$ \\
\hline $\begin{array}{l}\text { Sargan Test } \\
\text { P-Value }\end{array}$ & $\begin{array}{l}- \\
-\end{array}$ & - \\
\hline $\begin{array}{l}\mathrm{AB} \text { Test } \mathrm{m} 1 \\
\mathrm{P} \text {-value }\end{array}$ & $\begin{array}{l}1.2130 \\
0.214 \\
\end{array}$ & $\begin{array}{c}-2.0112 \\
0.0443 \\
\end{array}$ \\
\hline $\begin{array}{l}\text { AB Test } \mathrm{m} 2 \\
\mathrm{P} \text {-value }\end{array}$ & $\begin{array}{c}-1.5872 \\
0.1215 \\
\end{array}$ & $\begin{array}{l}0.1757 \\
0.8686 \\
\end{array}$ \\
\hline
\end{tabular}


Table A.2: Impact of Channel Specific Transfers on States' Tax Effort: Estimation Results of Linear Specification (GMM)

\begin{tabular}{|c|c|c|c|}
\hline Dependent Variable & $\begin{array}{c}(1) \\
\text { OTSDP }\end{array}$ & $\begin{array}{c}(2) \\
\text { OTSDP }\end{array}$ & $\begin{array}{c}(3) \\
\text { OTSDP }\end{array}$ \\
\hline Lag Dependent & $\begin{array}{l}0.7906^{*} \\
(16.46)\end{array}$ & $\begin{array}{l}0.7892 * \\
(16.83)\end{array}$ & $\begin{array}{c}0.79252 * \\
(20.09)\end{array}$ \\
\hline PGSDP & $\begin{array}{c}-0.000033 \\
(-1.32)\end{array}$ & $\begin{array}{c}-0.00004 * * \\
(-2.10)\end{array}$ & $\begin{array}{c}-0.000042 * * * \\
(-1.95)\end{array}$ \\
\hline NPRSC & $\begin{array}{c}0.03298^{*} \\
(3.31)\end{array}$ & $\begin{array}{c}0.0282^{*} \\
(2.67)\end{array}$ & $\begin{array}{l}0.028728^{*} \\
(3.12)\end{array}$ \\
\hline URBAN & $\begin{array}{l}0.02603 \\
(1.48 \quad) \\
\end{array}$ & $\begin{array}{c}0.0385^{*} \\
(2.71) \\
\end{array}$ & $\begin{array}{c}0.03617 * * \\
(2.59) \\
\end{array}$ \\
\hline PCSTT & $\begin{array}{c}-0.00024 * * \\
(-1.97)\end{array}$ & - & - \\
\hline PCGSP & - & $\begin{array}{c}0.000021 \\
(0.74)\end{array}$ & - \\
\hline PCDSG & - & - & $\begin{array}{c}-0.00015 \\
(-0.29) \\
\end{array}$ \\
\hline $\begin{array}{l}\text { Wald Test } \\
\text { P-value }\end{array}$ & $\begin{array}{c}1483.11 * \\
0.000 \\
\end{array}$ & $\begin{array}{c}1176.26^{*} \\
0.000\end{array}$ & $\begin{array}{l}1130 * \\
0.000\end{array}$ \\
\hline $\begin{array}{l}\text { Sargan Test } \\
\text { P-Value }\end{array}$ & - & - & - \\
\hline $\begin{array}{l}\text { AB Test } \mathrm{m} 1 \\
\text { P-Value }\end{array}$ & $\begin{array}{l}-3.4123 \\
0.0006\end{array}$ & $\begin{array}{l}-3.5187 \\
0.0004\end{array}$ & $\begin{array}{l}-3.515 \\
0.0004\end{array}$ \\
\hline $\begin{array}{l}\text { AB Test } \mathrm{m} 2 \\
\mathrm{P} \text {-Value }\end{array}$ & $\begin{array}{l}1.2187 \\
0.2229\end{array}$ & $\begin{array}{l}1.2004 \\
0.2300\end{array}$ & $\begin{array}{l}1.2298 \\
0.2188\end{array}$ \\
\hline
\end{tabular}

Notes: $t$-values are given in parentheses; *, ** and ***denote significance at $1 \%, 5 \%$ and $10 \%$ level respectively.

Table A.3: Impact of Aggregate Transfers on States' Own Tax Effort Instrumental Variable Estimation Results

\begin{tabular}{|l|c|c|}
\hline \multicolumn{1}{|c|}{ Dependent Variable } & OTSDP & PCOTR \\
\hline \multirow{2}{*}{ PCAEX } & $-0.00137^{*}$ & -0.055745 \\
& $(-2.61)$ & $(-1.51)$ \\
\hline \multirow{2}{*}{ PGSDP } & $0.000417^{* * *}$ & $0.05796^{*}$ \\
& $(1.82)$ & $(17.30)$ \\
\hline \multirow{2}{*}{ NPRSC } & $0.17302^{*}$ & $11.935^{*}$ \\
& $(3.58)$ & $(3.53)$ \\
\hline \multirow{2}{*}{ PARTC } & 0.00311 & $-0.1089^{* *}$ \\
& $(1.20)$ & $(-2.35)$ \\
\hline Wald Test & $6229.29^{*}$ & $2206.12^{*}$ \\
P-value & 0.0000 & 0.0000 \\
\hline
\end{tabular}

Notes: $t$-values are given in parentheses; $*, * *$ and $* * *$ denote significance at $1 \%, 5 \%$ and $10 \%$ level respectively; and here tax effort variables like OTSDP and PCOTR are modelled with instrumented expenditure (PCAEX). As density of population is used as instruments for the expenditure, the use of urbanisation (URBAN) as one of regressers is avoided. 
38 | VISION: Journal of Indian Taxation, Volume 4, Issue 2, Jul-Dec 2017

Table A.4: Impact of Aggregate Transfers on States' Spending: Estimation Results of Log-Linear Specification (GMM)

\begin{tabular}{|l|c|c|c|}
\hline \multicolumn{1}{|c|}{ Dependent Variable } & $(\mathbf{1})$ & $(\mathbf{2})$ & $(\mathbf{3})$ \\
& PCAEX & PCREX & PCCAD \\
\hline Lag Dependent & $0.2416^{*}$ & $0.2753^{*}$ & $0.3914^{*}$ \\
& $(13.71)$ & $(7.15)$ & $(10.33)$ \\
\hline PGSDP & $0.5858^{*}$ & $0.7383^{*}$ & 0.1918 \\
& $(17.25)$ & $(12.95)$ & $(1.56)$ \\
\hline POPDN & -0.0010 & -0.0460 & 0.2060 \\
& $(-0.01)$ & $(-0.58)$ & $(0.82)$ \\
\hline PARTC & $1.0744^{*}$ & $0.9940^{*}$ & $0.2554^{*}$ \\
& $(9.53)$ & $(8.29)$ & $(5.38)$ \\
\hline Wald Test & $11321.18^{*}$ & $6937.16^{*}$ & $509.12^{*}$ \\
P-value & 0.000 & 0.000 & 0.000 \\
\hline AB Test m1 & -3.3327 & -2.6353 & -1.1476 \\
P-Value & 0.0009 & 0.0084 & 0.2511 \\
\hline AB Test m2 & -0.01949 & -0.6086 & 1.3035 \\
P-Value & 0.9845 & 0.9515 & 0.1924 \\
\hline
\end{tabular}

Notes: $t$-values are given in parentheses; $*, * *$ and $* * *$ denote significance at $1 \%, 5 \%$ and $10 \%$ level respectively; one step system GMM estimates with robust standard error.

Table A.5: Impact of Channel Specific Transfers on States' Spending Estimation Results of Linear Specification (GMM)

\begin{tabular}{|l|c|c|c|}
\hline \multicolumn{1}{|c|}{ Dependent Variable- } & $\begin{array}{c}(\mathbf{1}) \\
\text { PCAEX }\end{array}$ & $\begin{array}{c}(\mathbf{2}) \\
\text { PCAEX }\end{array}$ & $\begin{array}{c}(3) \\
\text { PCAEX }\end{array}$ \\
\hline \multirow{2}{*}{ Lag Dependent } & $0.8537^{*}$ & $0.8088^{*}$ & $0.9103^{*}$ \\
& $(81.68)$ & $(40.55)$ & $(69.67)$ \\
\hline \multirow{2}{*}{ PGSDP } & $0.0471^{*}$ & $0.0863^{* * *}$ & $0.0817^{* * *}$ \\
& $(3.84)$ & $(1.90)$ & $(1.69)$ \\
\hline POPDN & -0.14745 & -0.1699 & -1.8828 \\
& $(-0.16)$ & $(-0.12)$ & $(-0.77)$ \\
\hline PCSTT & $1.0574^{*}$ & - & - \\
\hline PCGSP & $(7.82)$ & $0.8138^{*}$ & - \\
\hline PCDSG & - & $(7.46)$ & $2.4036^{*}$ \\
\hline Wald Test & - & - & $(2.90)$ \\
P-value & $116304.39^{*}$ & $44532.09^{*}$ & $47229.31^{*}$ \\
\hline Sargan Test & 0.000 & 0.000 & 0.000 \\
P-Value & - & - & - \\
\hline AB Test m1 & - & - & - \\
P-Value & -1.433 & -1.3241 & -1.4297 \\
\hline AB Test m2 & 0.1519 & 0.1855 & -0.1528 \\
P-Value & -0.36912 & -0.68916 & 0.5413 \\
\hline
\end{tabular}

Notes: $t$-values are given in parentheses; *, ** and ***denote significance at $1 \%, 5 \%$ and $10 \%$ level respectively; and @ indicates two step system GMM estimates with robust standard error. 